IZA DP No. 5639

Worktime Regulations and Spousal Labour Supply

Dominique Goux

Eric Maurin

Barbara Petrongolo

April 2011 


\title{
Worktime Regulations and Spousal Labour Supply
}

\author{
Dominique Goux \\ CREST
}

\section{Eric Maurin}

PSE and IZA

\author{
Barbara Petrongolo \\ Queen Mary, University of London, \\ CEP, LSE and IZA
}

\section{Discussion Paper No. 5639 \\ April 2011}

\author{
IZA \\ P.O. Box 7240 \\ 53072 Bonn \\ Germany \\ Phone: +49-228-3894-0 \\ Fax: +49-228-3894-180 \\ E-mail: iza@iza.org
}

\begin{abstract}
Any opinions expressed here are those of the author(s) and not those of IZA. Research published in this series may include views on policy, but the institute itself takes no institutional policy positions.

The Institute for the Study of Labor (IZA) in Bonn is a local and virtual international research center and a place of communication between science, politics and business. IZA is an independent nonprofit organization supported by Deutsche Post Foundation. The center is associated with the University of Bonn and offers a stimulating research environment through its international network, workshops and conferences, data service, project support, research visits and doctoral program. IZA engages in (i) original and internationally competitive research in all fields of labor economics, (ii) development of policy concepts, and (iii) dissemination of research results and concepts to the interested public.
\end{abstract}

IZA Discussion Papers often represent preliminary work and are circulated to encourage discussion. Citation of such a paper should account for its provisional character. A revised version may be available directly from the author. 
IZA Discussion Paper No. 5639

April 2011

\section{ABSTRACT}

\section{Worktime Regulations and Spousal Labour Supply}

We investigate spillovers in spousal labour supply exploiting independent variation in hours worked generated by the introduction of the shorter workweek in France in the late 1990s. We find that female and male employees treated by the shorter legal workweek reduce their weekly labour supply by about 2 hours, and do not experience any reduction in their monthly earnings. While wives of treated men do not seem to adjust their working time at either the intensive or extensive margins, husbands of treated wives respond by cutting their workweek by about half an hour to one hour, according to specifications and samples. In particular, managers and professionals respond much more strongly to the shorter legal workweek in their wives' firms than men in lower occupations. These effects are consistent with the presence of significant cross-hour effects on labour supply for husbands, though not for wives.

JEL Classification: J22

Keywords: spill-over effects, labour supply, workweek reduction

Corresponding author:

Dominique Goux

Centre de Recherche en Economie et Statistique

3 avenue Pierre Larousse

92245 Malakoff Cedex

France

E-mail: dominique.goux@ensae.fr

\footnotetext{
* We thank Philippe Askenazy for helpful discussions as well as participants at the CEPR conference on "Economics of Family Policy" in Bergen, participants at the Edmond Malinvaud seminar at CREST, as well as seminar participants at PSE and OECD.
} 


\section{Introduction}

Complementarities in labour supply and leisure time have long been identified as a key policy issue, as they represent an important channel through which reforms targeted at specific segments of the population can ultimately affect a wider sample of individuals. For example, work-sharing reforms can affect the value of leisure time in all layers of society, even when they are implemented in a few industries only (Alesina et al. 2005). When the value of leisure time for individuals depends on the amount of leisure enjoyed by their family members, coworkers, neighbours, social contacts, etc., reforms of the welfare state, or tax reforms, or changes in workweek regulations aimed at some segments of the workforce may impact individual behaviour well beyond the targeted population.

While spillover effects in leisure and work represent an important and controversial issue, there is still little micro-economic evidence on the actual magnitude of these effects. One major difficulty is that changes in leisure time and working hours for individuals are in most cases associated with important changes in their earnings. Thus the labour supply responses of 'peers' cannot be interpreted as reflecting pure cross-hour effects, as they may also encompass cross-earning effects. In this paper, we exploit the specific design of the workweek reduction policy implemented in France in the late nineties to overcome these issues and to provide one of the very first micro-economic estimates of the effect of an exogenous change in individuals' number of hours worked on the labour supply decisions of their spouses.

In June 1998 the French socialist government passed a law imposing a 10\% reduction of the legal workweek, from 39 to 35 hours, to be implemented in large firms by January 2000, and in small firms by January 2002. The law stipulated that employers who would implement the new legal norm through a collective agreement with trade unions before the deadline would benefit from significant cuts in their payroll taxes. At the same time, the law imposed that workers should not experience a decline in their monthly earnings after the agreement. The purpose of the reform was to raise the overall employment level via worksharing, while at the same time offering firms significant fiscal advantages in order to attenuate the impact of higher hourly wages on profitability. Overall, about 300,000 firms (employing roughly 35\% of the French workforce) signed a collective agreement before the come back of the conservative party to power in April 2002 and the interruption of the worksharing policy. In over one third of French households the reform induced a noticeable change in the workweek regulation of at least one spouse, with no direct impact on family income. 
This paper uses a unique matched worker-firm dataset obtained by combining the French Labour Force Survey with firm level information on the implementation of the shorter workweek, in order to estimate the labour supply response of husbands and wives to a reduction in the legal workweek of their spouses. We observe an average reduction of about 2 hours in the workweek of both male and female employees whose employers signed a workweek reduction agreement. ${ }^{2}$ When looking at spousal responses, we find that wives do not adjust their labour supply, whether at the intensive or extensive margin, when their husbands become treated. Husbands of treated women, by contrast, tend to work about 0.5 hours less per week, and this effect is robust whether or not the husband's own employer signed a workweek reduction agreement at the same time as the wife's employer.

Further tests reveal that husbands' labour supply response is not associated with a reduction in paid work, and as such should be interpreted as a reduction in some form of "unpaid work", which could reflect a higher take-up rate of paid leaves, or a reduction in unpaid overtime. If employees do not use their whole paid leave entitlement, and/or perform unpaid overtime work, they have some leeway in cutting their hours while avoiding earnings losses, and it seems that it is mostly by adjusting around these unpaid work margins that husbands respond to shorter workweek agreements in their wives’ firms.

These estimates are all the more suggestive as the direct (first-stage) effect of shorter workweek agreements on treated wives is estimated to be only about 2 hours. Assuming that the workweek reduction in wives' firms affects husbands only via wives' number of hours worked, we provide an IV estimate of the average cross-hour effect for husbands of 0.24 , rising to 0.38 for managers and professionals, and to 0.58 for fathers of young children. By contrast, the symmetric cross-hour effect on wives’ labour supply is negligible.

Our estimated spillover effects would imply a value for the social multiplier in households' labour supply in the range 1.1 to 1.3, depending on household composition. That is, the equilibrium labour supply response to an exogenous shock is about $10 \%$ - $30 \%$ larger than the initial impact. As discussed by Glaeser et al. (2003), the role of social interactions and social multipliers may vary widely across behavioural outcomes and levels of aggregation, and the French reform provides a unique opportunity to identify the multiplier in labour supply at the level of households.

\footnotetext{
${ }^{2}$ As discussed below, there are various reasons why the average effect of the shorter legal workweek on actual weekly hours is lower than the legal workweek reduction, including the fact that the shorter legal workweek may not have been binding for employees initially working below 35 hours.
} 
By looking at labour supply spillovers within households, our paper contributes to the existing literature on spouses' joint labour supply behaviour. This literature typically investigates the response of an individual's labour supply to independent changes to her spouse's income and/or hours of work (Lundberg, 1988). These changes can be in turn driven by retirement (Hurd, 1988, and Gustman and Steinmeier, 2000), job loss (Lundberg, 1985, Cullen and Gruber, 2000), or tax reforms (Gelber, 2010). While focusing on very different sources of variation, these papers tend to agree in documenting significant spillovers in the labour supply decisions of spouses. Our contribution to this literature is threefold. First, we exploit independent variation in spousal hours of work, while keeping monthly earnings constant. This allows us to abstract from income effects of changes in spouses' hours worked, and focus on pure cross-hour effects. Secondly, while most of the existing literature has focused on the labour supply response of secondary earners, we show in this paper that it is in fact husbands who significantly cut their working hours following the adoption of the shorter workweek in their wives' workplaces, while the corresponding wives' response is zero. This may be in turn due to different degrees of leisure complementarities in spouses' utility functions, or a higher ability of men to control their working schedules. Thirdly, we provide evidence on specific adjustment margins in labour supply spillovers, and specifically we find that it is mostly husband's unpaid involvement in their workplace that is affected when their wives’ workweek is reduced.

Our paper is also related to the literature on work-sharing policies in western countries. The study which is closest to ours is Hunt (1998), who shows that the gradual decline in "standard working hours" of male, German employees between 1984 and 1994 was not accompanied by changes in their wives' employment rates, but nevertheless produced a small decline in their hours of work. These results, while consistent with complementarity between spousal leisure, may also reflect underlying trends in female labour supply in Germany over this period, including wives’ own gradual exposure to shorter standard workweeks.

Finally, our paper adds to the literature evaluating the effects of the workweek reduction in France (see e.g. Askenazy, 2008, Crépon and Kramarz, 2002, Crépon, Leclair and Roux, 2004, Estevao and Sa, 2008). Existing evaluations typically compare own outcomes for employees in large and small firms, who were exposed to the workweek reduction in 2000 and 2002, respectively. In this paper we exploit variation in the exact dates of implementation of the workweek reduction across firms to investigate the labour supply response of individuals to their spouse's reduction in working hours. 
The paper is organised as follows. Section II gives an overview of the workweek reduction reform. Section III describes the data used and provides some graphic analysis of the effect of the workweek reduction on treated individuals and their spouses. Section IV presents our main regression results. Section V shows robustness of our results to alternative identification strategies. Section VI provides IV estimates of cross-hour effects, using mandated workweek reductions as instruments for spouse labour supply. Section VII finally concludes.

\section{Historical and institutional context}

Since the early eighties, the legal workweek in France has been 39 hours. Overtime wage bonus was $25 \%$, and the maximum number of overtime hours per worker was set at 130 per year. In 1993, the French economy went through one of the most severe recessions of the post-war period, accompanied by a rapid increase in unemployment, reaching the peak rate of $12 \%$ in 1996. In this highly depressed context, the French conservative government passed a law offering private firms fiscal incentives to increase their number of employees through a workweek reduction (Robien law). The impact of the Robien law was very limited however, with less than 3,000 agreements signed with unions, affecting less than $2 \%$ of the workforce (see Fiole and Roger, 2002). The law did not modify the legal workweek, which remained at 39 hours.

In April 1997, the French president Jacques Chirac dissolved the parliament and called general elections one year ahead of the end of the legislature. The decision was highly unexpected and the following electoral campaign was very short. The socialist party proposed a program whose main axis was the reduction of unemployment through worksharing, with two basic slogans: "travailler moins pour travailler tous" (work less in order to work all) and “35 heures payées 39” (35 worked hours paid 39). The left coalition won the election in June 1997.

The workweek reduction was implemented in two successive steps (see Askenazy, 2008, for a detailed presentation in). The first law (Aubry I) was passed in June 1998. It set the legal workweek at 35 hours in the private sector and mandated that the new workweek be implemented by January 2000 in firms with more than 20 employees, and by January 2002 in smaller firms. Hours worked beyond the $35^{\text {th }}$ hour would be treated as overtime hours, subject to a $25 \%$ hourly wage bonus and to a maximum of 130 overtime hours per employee per year.

Also, the law stipulated that firms who would implement the shorter workweek through a collective agreement with unions before the relevant deadline would benefit from a 
cut in payroll taxes, ${ }^{3}$ provided that they commited to maintain employment levels. Finally, the law required that workers should not experience a drop in their monthly earnings following the legal workweek reduction. In particular, firms who passed a 35-hours agreement had to grant specific (4 hours) bonus to workers paid the monthly minimum wage. The general purpose of the law was to induce firms to raise employment levels by worksharing, while offering firms fiscal advantages to attenuate any detrimental impact of this reform on profitability.

In January 2000, the second law (Aubry II) introduced several additional regulations in order to limit the cost of the shorter workweek for employers. In particular, it became possible to implement the shorter workweek via slightly modified definitions of working time, without losing eligibility for fiscal aids. For example, it became possible for employers to exclude "unproductive breaks" from the definition of working time. Also, it became possible to introduce shorter working hours on an annual - rather than weekly - basis, with a cap on annual hours being set at 1600 . In practice it means that a collective agreement could be signed (and fiscal advantages obtained) even with actual reductions of working hours below $10 \%$ (holding definition of work time constant). Most importantly, the new law introduced a two-year transitional phase during which it became possible for employers to keep the 39hour workweek by using overtime at a reduced $10 \%$ rate. ${ }^{4}$

Two years later, in summer 2002, the conservative party came back to power and the whole transition to the shorter workweek was interrupted. Small firms could benefit from a postponement of the 35-hour deadline (until 2005). As a consequence, the 35-hour was never fully implemented, especially in small private firms. Nevertheless, the Aubry laws have had a very large impact on the French economy, with about 350,000 agreements signed corresponding to about 10 millions of workers, but the process was finally interrupted long before the full implementation of the new norm.

To sum up, the French workweek reform had several important features: it was unexpected and implemented over a relatively short period of time; it has been interrupted, with only a fraction only of workers being affected; it did not affect monthly earnings; and given its gradual implementation it would likely not treat spouses in a given household at the same time.

\footnotetext{
${ }^{3}$ For workers paid at the minimum wage, the tax cut corresponds to a reduction of about $8 \%$ in total labour cost for 5 years.

${ }^{4}$ Furthermore, employers were not bound to a maximum of 130 overtime hours anymore and no longer required to commit to maintain employment levels in order to be eligible for payroll tax cuts.
} 
In the remainder of this paper, we will build on these features of the reform in order to evaluate the effect of an exogenous variation in an individual's workweek on the number of hours worked by the other spouse.

\section{Data and descriptive evidence}

\section{1 Data}

In this paper we combine individual level information on worker characteristics and working hours with firm level information on collective agreements signed by employers who adopted the shorter workweek.

We use individual records from the French Labour Force Surveys (hereafter, LFS), which is conducted each year by the French Statistical Office (Institut National de la Statistique et des Etudes Economiques, herafter, INSEE). Before 2003, the LFS is conducted every March, and covers a representative sample of about 100,000 households each year (with a 1/300 sampling rate). From 2003 onward, the survey is conducted each quarter and covers a representative sample of about 55,000 households each quarter. In what follows we use all annual surveys for 1994-2002, and the first quarterly survey for 2003-2009.

For each household member aged 15 or above, the LFS provides information on sex, marital status, employment status, occupation, educational level, industry, monthly earnings and hours worked during the previous week. Crucial for our purposes, our restricted use version of the LFS also provides the identification number of the employer. Specifically, each employee is asked to report the name and address of her employer, and this information is coded by INSEE. The coded employer identifier is available for just over $80 \%$ of the employees in the $\mathrm{LFS}^{5}$. This information allows us to match worker level information with firm level information from the "DARES-URSSAF" dataset, an administrative database collected by the French Ministry of Labor, which provides detailed information on all firms who signed a workweek reduction agreement, including the signing and implementation dates. We thus obtain a matched employer-employee dataset containing information on working hours of respondents and their spouses (if any), as well as information on when, if at all, their employers implemented the shorter workweek.

\footnotetext{
${ }^{5}$ Most cases with missing employer ID correspond to very small firms. For an early use of this information and a detailed description of the coding procedure, see Entorf, Gollac and Kramarz (1999) and Goux and Maurin (1999).
} 
In what follows we focus on a sample of married or cohabiting respondents, whose spouse is a wage-earner, and we focus on the labour supply response of respondents to spousal exposure to the shorter workweek. We restrict analysis to respondents aged 18-65, and drop a small fraction of respondents whose spouses' firm signed an agreement either before 1996 or after 2002, since it is not clear whether these early and late agreements really correspond to the reforms implemented in the late 1990s. Our working sample includes 189,894 males and 236,802 females. We will also look at subsamples of employed respondents, workers on high-skill occupations, workers on low-skill occupations, etc.

\section{III.2 Descriptive statistics}

Table 1 provides some basic descriptive statistics on our sample, distinguishing between male and female respondents, and by the treatment status of their spouses. Throughout the paper we defined as treated all spouses whose employers ever implement a workweek reduction agreement. Both men and women are less likely to work in the public sector when they have a treated spouse, which is consistent with the reform having mostly affected the private sector. But the age and years of education of men are nonetheless very similar whether or not their wives are treated, and similarly for women.

Table 2 reports the distribution of own and spousal legal workweek status in the employed sample, and shows that about $54 \%$ of husbands of treated wives are non-treated themselves by the workweek reduction (Panel A, column 1), while about $29 \%$ of husbands of non-treated wives are treated. Thus there is some assortative mating along the workweek dimension, but spouses have nonetheless different treatment status in a large proportion of cases. Also, even when both spouses are treated, the timing of treatment differs for about half of couples. Panel B shows a very similar picture for wives of treated and non-treated husbands. To further illustrate timing of treatment, Figure 1 graphically shows the gradual implementation of the shorter workweek for spouses of employed respondents, i.e. on the same sample described in Table 2. While only about a third of employees is eventually treated in this sample, there is substantial variation in treatment dates between 1998 and 2002.

The matched employer-employee dataset used has some clear advantages compared to the non-matched LFS, which is typically used in existing evaluations of the French workweek reduction. First, it allows us to identify which workers were actually treated, and not simply the intention to treat based on the number of employees of their firms and the proximity to the law deadlines ${ }^{6}$. Also, the information on the exact date of treatment makes it possible to

\footnotetext{
${ }^{6}$ For example, a recent contribution by Ahmed (2009) compares wives' labour market transitions before and after 1998 using the small fraction of wives whose husbands are part-timers in small firms as a control group.
} 
exploit the gradual implementation of the shorter workweek, whereas previous studies had to rely on the announced 2000 and 2002 deadlines. In particular, the information on exact dates of treatment allows us to separately identify the direct and cross-effects of shorter workweeks across spouses, as in the majority of cases the year of treatment differs across spouses.

\section{3 Graphical evidence: Direct and indirect effects of treatment}

Before moving on to our regression analysis, below we provide some simple graphical evidence on the direct and indirect effects of the 35-hour reform on the number of hours worked by husbands and wives. Figure 2 plots hours worked during the survey week by wives who are wage earners, by treatment status $(189,894$ observations in total). The solid line refers to treated women, and time zero refers to the year in which a shorter workweek agreement is implemented at their workplace. Their workweek length is stable, if anything slightly rising during the pre-treatment years, and drops by about 2 hours upon treatment. The dotted line refers to non-treated women, and reports their working hours for the same dates at which treated wives were observed. Their hours follow a gradually rising trend throughout the sample period, with no break at time 0 . Thus we observe a decline of about 2 hours in working hours of treated wives relative to control wives at time of the treatment. Interestingly, wives that become treated have longer weekly hours initially, and their hours converge almost exactly to hours of non-treated wives when their employers adopt the shorter workweek.

This first-stage effect of the shorter workweek on actual hours worked is about one half the shortening in the legal workweek and this may be explained by a number of factors. In particular, part of the implementation of the worktime regulation may have taken place with slight modifications of working time definition (for example excluding unproductive breaks from the hours count) or reducing the number of weeks worked per year rather than the number of hours worked per week, keeping usual weekly hours constant (see also Askenazy, 2008). This would deliver a mitigated effect of the workweek reduction on mean actual hours worked, as the survey week falls in March of each year, and thus tends not to coincide with popular holiday seasons. Finally, the effect of the introduction of the 35-hour workweek has also been mitigated by the fact that about 30\% of French female employees work part-time, and for them the shorter workweek would not be binding. The estimated 2-hour drop in working hours can be interpreted as an average of a higher drop for women initially working more than 35 hours, and a smaller drop for women initially working less than 35 hours ${ }^{7}$.

\footnotetext{
${ }^{7}$ This specific explanation would not work for men, as the proportion of part-timers among male employees is negligible.
} 
Given the behaviour of treated wives, the next question is whether we observe a variation in either the employment rate or the number of hours worked by their husbands. This is addressed in Figure 3, which shows flat and virtually identical employment patterns of husbands of treated and non-treated wives. When focusing on a $[-3,+3]$ years window around time of treatment, the difference in employment rates between husbands of treated and nontreated wives is very small (about 1.5 percentage points) and almost exactly the same before and after the date of the treatment. Thus we detect zero spillover effects at the extensive margin.

Figure 4 then addresses the intensive margin, by showing the impact on hours worked by the subsample of employed husbands, and reveals a sizeable drop in average working hours of husbands of treated wives, relative to husbands of non-treated wives. Specifically, the difference in working hours between the treatment and control group was close to zero during the five pre-treatment years, and rose to nearly 1 during the 5 post-treatment years.

These spillover effects may in part reflect the fact that some husbands were themselves employed in firms who adopted the shorter workweek, and thus became treated at the same date as their wives. To purge this effect out, we replicated the same trends on a sub-sample that excludes households in which spouses became treated at the same date (see Figure A1 in appendix), and still observe a clear change in the relative number of hours worked by husbands of treated wives at the time of treatment. The same result holds when we further restrict the sample to households in which the husband was never treated (see Figure A2). In the regression analysis that follows we will pool all households and control for own and spouse treatment separately.

Figures 5 to 7 repeat a similar analysis for male employees and their wives. Again we observe a clear drop in working hours of treated relative to non-treated husbands (Figure 5), whose magnitude is very close to that we observed for wives in Figure 2. However, we find no evidence of spillover effects on their wives' labour supply, either at the extensive margin (Figure 6), or the intensive margin (Figure 7).

To summarize, our descriptive evidence is suggestive of labour supply spillovers at the intensive margin for husbands of treated wives, but no spillovers at the extensive margins or for wives of treated husbands. In the next section we'll provide estimates of these effects that control for observable characteristics of the individuals, and explore further the nature of these spillovers.

\section{Regression results}




\section{IV.1 Main estimates}

We focus on two main outcome variables for each individual $i$ in our sample, namely her employment status and her weekly hours worked, and assess how each is affected by the implementation of a shorter workweek agreement by her spouse's employer. This would work via an effect on the spouse's labour supply, and thus we initially estimate a first-stage specification that regresses spouse working hours on treatment variables and other covariates. We denote by $H S_{\text {it }}$ the actual weekly hours worked by the spouse, and introduce a dummy variable $A S_{i}$ indicating whether she works for a firm who has ever adopted the shorter workweek. Our first-stage regression is the following difference-in-differences specification:

$$
H S_{\text {it }}=\gamma_{1} X S_{\text {it }}+\alpha_{1} A S_{\text {it }}+\beta_{1} A S-\text { post }_{\text {it }}+D_{\mathrm{t}}+\mathrm{u}_{\mathrm{it}},
$$

where $A S$-post ${ }_{\text {it }}$ indicates the period following a workweek reduction in the firm of the spouse, $D_{\mathrm{t}}$ denotes a set of year fixed effects, and $X S_{\text {it }}$ are relevant individual covariates, including a constant term. The $\beta_{1}$ coefficient shows the direct effect of workweek regulations on labour supply. Table 3 shows the regression results for specification (1) for wives (Panel A) and husbands (Panel B). Column (1) in Panel A shows that wives working in firms who implemented a workweek reduction agreement were working about 1.36 hour more than wives in other firms in the pre-reform period, but then cut their labour supply by about 1.81 hour per week once the shorter workweek was implemented. This pattern of working hours was also evident from Figure 2, and the only difference here is that we control for aggregate time effects and a public sector dummy. Turning to husbands, column (1) in Panel B shows small pre-treatment differences (-0.28 hour), but again strong and significant effects of the workweek reduction (-1.95 hour). All these estimates are robust to the introduction of controls for age, education and industry effects in column (2), suggesting that the implementation of the shorter workweek was largely orthogonal to these job and worker characteristics.

Columns (3) and (4) report estimates of a similar specification for (the log of) monthly earnings, and once extra controls are included these show near zero effects of the workweek reduction on the earnings of wives and husbands. These first-stage results are clearly in line with the reform intention to shorten the workweek without cutting monthly earnings of treated employees. If anything, the effect of the shorter workweek on the monthly earnings of husbands is positive rather than negative, albeit tiny, and only significant at the $10 \%$ level.

We next assess labor supply spillovers by looking at the reduced-form effects of the workweek reduction in the spouse firm on the employment status of the main respondent and her weekly hours. Note that we can interpret such cross effects as stemming from the sole 
reduction in the amount of time spent at work by the spouse once we have ruled out the presence of income effects, as shown in columns (3) and (4) of Table 3. Our reduced-form specification for employment is

$$
E_{\mathrm{it}}=\gamma_{2} X_{\mathrm{it}}+\alpha_{2} A S_{\mathrm{it}}+\beta_{2} A S \text {-post }{ }_{\mathrm{it}}+D_{\mathrm{t}}+v_{\mathrm{it}},
$$

where $E_{\mathrm{it}}$ is a dummy variable that is equal to 1 for the employed and 0 for the nonemployed. For hours worked, we restrict the sample to employed individuals and estimate

$$
H_{\text {it }}=\gamma_{3} X_{\text {it }}+\alpha_{3} A S_{\text {it }}+\beta_{3} A S-\text { post }_{\text {it }}+\delta_{3} A_{\text {it }}+\theta_{3} A-\text { post }_{\text {it }}+D_{\mathrm{t}}+\varepsilon_{\text {it }},
$$

where $H_{\text {it }}$ denotes weekly hours conditional on working. The $A_{\text {it }}$ variable is a dummy denoting whether the employer of the main respondent has ever implemented a shorter workweek agreement whereas $A$-post ${ }_{i t}$ indicates the period following this agreement. The main coefficients of interest are $\beta_{2}$ in model (2) and $\beta_{3}$ in model (3). Note that these specifications allow us to estimate cross effects in labor supply (represented by $A S$-post ${ }_{i t}$ ), over and above the direct effect stemming from the adoption of the shorter workweek in the own firm $(A$ post $_{i t}$ ). These two effects can be separately identified in so far treatment is not simultaneous for all spouses.

The regression results are reported in Table 4. Columns (1) and (2) refer to employment, and columns (3)-(5) refer to weekly hours. Estimates show no evidence of any significant cross effect on employment for either husbands or wives, and the associated point estimate is always very close to zero, in line with the trends reported in Figures 3 and 6. As we do not find any impact on employment, we can next look at hours worked for those who are employed. ${ }^{8}$ In column (3) of Panel A we regress husbands' hours on own treatment variables ( $A$ and $A$-post), and on their wives' treatment variables (AS and $A S$-post). The own treatment effect is again about $-1.9^{9}$, and the cross effect is -0.44 and highly significant. When their wife becomes treated by the shorter workweek, working men reduce their labour supply by nearly half an hour per week. The magnitude of this effect does not change when we control for individual characteristics of respondents (column (4)), or when we exclude own treatment variables $A_{\text {it }}$ and $A$-post it $_{\text {it }}$ (results not reported). Finally, the estimated cross effect gets somewhat larger (-0.50 hour) when we exclude husbands who are themselves treated at some point during the sample period (column (5)).

\footnotetext{
${ }^{8}$ We also estimated first-stage regressions like (1) for the employed subsamples, and the results are reported in Table A1 in the Appendix. The own effect of the shorter workweek is -1.8 hour for wives, and -2.1 hours for husbands, and again we find near zero effects on monthly earnings.

${ }^{9}$ Note that the own effect is virtually identical to that estimated in first-stage regressions reported in Panel B of Table 3. However the two samples may differ as Panel B of Table 3 covers male employees, and Panel A of Table 4 covers husbands of female employees.
} 
Panel B represents parallel estimates for wives. While the own effect of workweek regulations is negative and significant, the cross effect is positive, small, and not significantly different from zero.

Our estimates provide one of the very first pieces of evidence showing that changes in the workweek of a subsample of employees may have a very significant impact well beyond the targeted population. By focusing on the direct effect on targeted population, most existing evaluations of workweek reduction policies are likely to underestimate the effect of these reforms on overall labour supply. A simple back-of-envelope calculation can help quantify overall spillover effects. In particular, the adoption of the shorter workweek has implied a reduction of nearly two hours in the labour supply of married women, and nearly half an hour in the labour supply of their husbands. Assuming for simplicity that the same probability of treatment (0.35) and the same first stage effect ( -2 hours) would apply to all categories of workers, the average direct effect of the reform on the male labour supply would be $-0.35 \times 2=-0.7$ hours, whereas the average cross effect would be $-0.35 \times 0.61 \times 0.5=-0.11$ hours, where 0.61 represents the proportion of male workers who are married to a female wage earner. Thus neglecting indirect effects would underestimate the overall impact of the workweek reduction on male labour supply by about $0.11 /(0.11+0.7)=13 \%$. Given that men represent about half of the overall employed population, it would underestimate its impact on the overall population by about $0.11 /(0.11+0.7+0.7)=7.3 \%$.

\section{IV.2 Further estimates: Cross effects on paid and unpaid work}

We have shown that, following a workweek reduction at their workplaces, wives work 1.8 hours less per week at constant earnings, and their husbands respond by cutting their labour supply by about half an hour. The aim of this section is to assess the nature of these labour supply spillovers.

If husbands' labour supply response reflects a reduction in "unpaid" worktime, the estimated cross-hour effect could be unambiguously driven by spousal complementarities in non-market time. By contrast, if husbands' response involves a cut in paid worktime, it may also be the consequence of a substitution of wives' non-market activities for some family expenditure. For example, husbands may cut their paid hours simply because their wives use their additional non-market time to substitute for paid child-care.

The most direct way to explore this question is to test whether respondents' earnings are negatively affected by the workweek reduction in their spouses' firms. The two first columns of Table 5 show that it is clearly not the case. Using the same reduced-form 
specification as in Table 3, we find that if anything a workweek reduction agreement in the wife's workplace is associated which a $0.8 \%$ increase in husband's earnings, and this effect is hardly significant at the $10 \%$ level. This finding thus suggests that cross effect on husbands' labour supply mostly corresponds to a reduction in unpaid work.

To take this argument one step further, one should ideally exploit information on cross spouse effects on margins such as paid absences, absenteeism, or unpaid overtime. Unfortunately, detailed information on overtime and vacation time is only available in the LFS since 2003, well beyond the period of implementation of the workweek reduction reform.

The only indirectly related evidence that one could exploit for the earlier period is information on the difference between actual hours (that we denoted by $H$ ) and usual hours (that we will denote by $H_{u}$ ), defined as the number of hours worked in a typical week ${ }^{10}$. We define as overtime the magnitude $\left(H-H_{u}\right)^{+}=\left(H-H_{u}\right) * I\left(H-H_{u}>0\right)$, and as unworked hours the magnitude $\left(H-H_{u}\right)^{-}=\left(H-H_{u}\right) * I\left(H-H_{u}<0\right)$. Of course these are both weekly-aggregated measures, thus someone who works one hour longer than the typical workday for three days in a week and one hour shorter for the remaining two days would represent a case of overtime work according to our definition, and this simply means that her overtime hours more than offset her unworked hours during the week. Overall, usual hours $H_{u}$ are defined for about $85 \%$ of individuals in our sample, and they coincide with actual hours worked $H$ in only $73 \%$ of cases. We observe overtimes hours, i.e. $H>H_{u}$, in about $11.6 \%$ of cases and unworked hours, $H<H_{u}$, in about $15.3 \%$ of cases. Conditional on $H<H_{u}$, $57 \%$ of cases correspond to workers who did not work al all during the survey week, and among them the average of $\left(\mathrm{H}-\mathrm{H}_{u}\right)^{-}$is 38, and $43 \%$ of cases correspond to workers who worked positive hours but still below their usual workweek, and among them the average of $\left(H-H_{u}\right)^{-}$is -10 . Conditional on $H>H_{u}$, the average number of overtime hours is 7.4.

In theory, variations in $\left(H-H_{u}\right)^{+}$or $\left(H-H_{u}\right)^{-}$may be associated with variations in both paid or unpaid work. Specifically, $\left(H-H_{u}\right)^{+}$may include both paid and unpaid overtime hours, whereas $\left(H-H_{u}\right)^{-}$may capture both paid and unpaid absences from work. In practice, we find that while overtime hours do translate into higher earnings, unworked hours typically do not imply earnings losses. To illustrate this, Table A2 in the Appendix reports estimates from regressions of monthly earnings on $H_{u},\left(H-H_{u}\right)^{+}$and $\left(H-H_{u}\right)^{-}$separately for the 1994-2002

\footnotetext{
${ }^{10}$ According to the official ILO (2002) definition, usual hours per week represent "the modal value of the number of hours actually worked per week over a long period of time". This definition is applicable to workers with regular schedules only (about 85\% of cases in the LFS). It does not include irregular or unusual overtime (whether worked for a premium pay or not compensated at all) nor unusual absence or rest.
} 
period. ${ }^{11}$ Column 2 shows that earnings only respond significantly to usual and overtime hours, whereas unworked hours have no discernible impact, and columns 3-6 show that this result holds true within both the treated and the control sample. Thus variation in unworked hours seems to reflect variation in unpaid work.

To summarize, we have shown that the cross-hour effect for husbands is not associated with an earnings loss, and that in general variations in unworked hours are not associated with variations in earnings, while overtime hours are. The next question is whether the estimated cross-hour effect is indeed driven by a response in unworked hours. To this purpose, columns 3-6 of Table 5 repeat our reduced-form specification (3) using $\mathrm{H}_{u}, \mathrm{H}-\mathrm{H}_{u},\left(\mathrm{H}-\mathrm{H}_{u}\right)^{+}$and $\left(\mathrm{H}-\mathrm{H}_{u}\right)^{-}$ as dependent variables in turn. Interestingly, regressions show a sizeable cross-hour effect only for unworked hours, but none on either usual hours or overtime hours. In other words, the only hours concept that responds to spousal workweek treatment is one that typically would not have a discernible impact on earnings.

This analysis confirms that husbands' cross hour effects occur via a cut in unpaid work and thus it can be unambiguously interpreted as a consequence of complementarities in spousal nonmarket activities, most likely in leisure time. The reduction in unpaid worktime could in turn happen through an increase in the take-up rate of paid leave, or a rise absenteeism, or a cut in unpaid overtime. ${ }^{12}$ No direct information on these margins is available for the sample period of interest, but according to 2003-2009 LFS surveys, about $12 \%$ of male employees declare that their paid holiday entitlement exceeded the amount of paid leave actually taken by one week or more, $23 \%$ declare to have worked overtime in the survey week, and that over $61 \%$ of their overtime hours were unpaid. For employees in highskill occupations, about $37 \%$ have been working overtime, and about $84 \%$ of their overtime hours were not remunerated (see Appendix Table A3). These data are suggestive of significant leeway for most employees, and especially the highly skilled, in reducing their unpaid involvement in the workplace. The next subsection investigates such heterogeneous response in spousal labour supply.

\section{IV.3 Heterogeneous Cross-Hour effects}

\footnotetext{
${ }^{11}$ Information on $H_{u}$ is only available for the pre-2003 period.

${ }^{12}$ As mentioned above, as our measure of unworked hours is aggregated at the weekly level, husbands who report unworked hours in a given week may have worked overtime on some days of the week, and may cut on this margin when their wives become treated.
} 
As Table A3 shows, workers in high-skill occupations typically work longer hours than the less-skilled and are also more likely to do overtime work. High skill occupations include managers, engineers and professionals at various levels (cadres in the French classification of occupations), and cover about $20 \%$ of the employed workforce. About $51 \%$ of males in these occupations work more than 45 weekly hours, while only $24 \%$ of those in less-skilled occupations do so. For women, the proportions are 21\% and 8\% respectively. Moreover, highskill workers typically have higher control over the organization of their workweek. One could therefore expect that high-skill workers are more likely to respond to change in their spouses' work week than the less-skilled, who are instead more likely to work the legal workweek and therefore would only be able to cut their working hours via new contractual agreements.

To test this assumption, we replicate our previous analysis separately for husbands on high-skill occupations, and other husbands. The results are reported in Table 6, which shows in column (1) a strong and significant first-stage effect of the shorter workweek on wives' working hours, which is somewhat higher for wives of managers and professionals than for other wives. Interestingly, the associated cross effect on hours is about three times larger for managers and professionals than for other workers (column 2). In particular, managers and professionals cut their worktime by nearly one hour when their wives are treated, while the corresponding figure for workers in other occupations is about 19 minutes, and this effect is only borderline significant. One can draw similar conclusions looking at the probability of working more than 45 hours weekly (column 3), which shows that wives' treatment lowers the likelihood of a long workweek for husbands in managerial or professional jobs by 4 percentage points, representing an $8 \%$ reduction on the baseline proportion of $51 \%$. Spillover effects on husbands' labour supply thus seem a lot stronger for the high-skilled than for the less-skilled.

We further explore spousal labour supply responses in households with young children, as compared to other households. It has been argued that the interdependence of spousal labour supply may be stronger when there are young children in the household, as children appear to play the role of a "jointly-consumed commodity" for husbands and wives (Lundberg, 1988). To test this assumption, Table 7 replicates previous regressions for households with at least one child aged 0-6 and for other households separately. In first-stage regressions of column 1, we find weaker reductions in weekly hours for mothers of young children (-1.30) than for other women $(-2.08)$. This difference is to be expected, as about 37\% of mothers of children aged 0-6 work part-time, as opposed to $30 \%$ for other women, and for 
part-timers the mandatory workweek reduction would not necessarily be binding (BlochLondon and al., 2003). Moving to reduced-form regressions in column 2, the reaction of husbands to their wives' treatment is noticeably stronger in households with young children than in other households, despite a weaker first-stage effect. The presence of at least one young child thus clearly increases the reaction of husbands' labour supply to their wives working hours. Again we did not detect any similar spillovers for wives.

\section{Robustness checks}

\section{V.1 Alternative Identification}

The previous analysis uses two basic sources of identification for the spillover effects of 35hour agreements. Namely it exploits the fact some spouses are treated whereas others are not, and the fact that not all treated spouses are treated at the same date. To check the robustness of our estimates, Table 8 replicates the previous regressions using separately these two sources of identification separately. Specifically, the first-stage regression is based the following specification,

$$
\begin{aligned}
H S_{\mathrm{it}}=\gamma_{4} X S_{\mathrm{it}}+\alpha_{41} A S_{\mathrm{it}} & +\alpha_{42} A S_{\mathrm{it}} *(1998 \leq t \leq 2002)+ \\
& +\beta_{41} A S_{\mathrm{it}} *(t>2002)+\beta_{42} A S-\text { post }_{\mathrm{it}} *(t \leq 2002)+D_{\mathrm{t}}+\eta_{\mathrm{it}} .
\end{aligned}
$$

Holding $A S_{\text {it }}$ constant, the $\beta_{41}$ coefficient compares hours worked by those ever treated to hours of the nontreated. By contrast, holding $A S_{\text {it }}{ }^{*}(1998 \leq t \leq 2002)$ constant, the $\beta_{42}$ coefficient compares hours worked by those treated later to hours worked by those treated earlier. ${ }^{13}$

Columns 1 and 2 in the Table 8 show the estimated effects on wives' hours and earnings. Comfortingly, estimated $\alpha_{41}$ and $\alpha_{42}$ are both negative, highly significant, very similar to each other and very close to the overall effect obtained with the basic specification (see Table 3). Column 3 shows $\beta_{41}$ and $\beta_{42}$ the two corresponding cross effects on husbands' hours. Most interestingly, these two effects are negative, significant, and close to each other. Also, these estimates are similar to those obtained with the basic specification (see Table 3). Turning to females, the estimated cross effects are still negative, but smaller in magnitude and not significantly different from zero at standard levels, regardless of the source of identification (results not reported).

\footnotetext{
${ }^{13}$ Note that $A S$-post $\equiv A S$-post* $(t \leq 2002)+A S^{*}(t>2002)$ so that Model (3) and Model (4) are nested. In particular, Model (3) is a special case of Model (4), in which we impose $\alpha_{41}=\alpha_{42}$ and $\beta_{41}=\beta_{42}$.
} 


\section{V.2 Fixed-effect estimates}

The French LFS has a rotating panel dimension, with one third of the sample being replaced each year, and each household typically staying in the sample for two years (three surveys). In this section we exploit this longitudinal component to provide panel estimates of the effect of the shorter workweek on spousal labour supply. An important caveat is that the longitudinal dimension available is quite short, and spells of observation of respondents only rarely overlap with the adoption of the shorter workweek in their spouses' firms. Even when we focus on the $1998-2002$ period $^{14}$, only about $10 \%$ of respondents surveyed are observed both before and after the implementation of the shorter workweek in their spouses' firms (see Table 9). Overall, only about 23,000 male and 29,000 female respondents can actually contribute to the identification of changes in spouses' firm regulation on respondents' labour supply.

With these caveats in mind, we replicate previous regressions controlling for individual fixed. Table 10 reports estimates of reduced-form effects on employment, hours and earnings. Employment and earnings effects of the shorter workweek are again nil. The direct hours effect is negative and significant for both women (-1.22) and men (-1.21), although this is somewhat smaller than the effect detected in cross-section estimates of Table 3. As fixed-effect estimates focus by construction on short-term effects of worktime agreements, while cross-sectional estimates exploit a longer horizon, one may think that the difference between the two may be due to some gradual implementation of the shorter workweek. Figures 2 and 5 show that this may be the case for husbands, though not for wives. Another possible interpretation is that panel estimates may be more seriously affected by measurement error in the actual date of implementation of the shorter workweek, which would generate a stronger attenuation bias in fixed-effect estimates. The cross hour effect for husbands is negative, although this only becomes significant when one looks at the difference between actual and usual hours, and again it is the amount of unworked hours that is adjusted following wives' shorter workweeks (-0.8 hour). For wives, the cross-hour effect is either positive or close to zero, but never statistically significant. Overall, our main findings are robust to the introduction of individual fixed-effects, although the significance of various effects is reduced in this smaller sample.

\footnotetext{
${ }^{14}$ Households surveyed either before 1998 or after 2002 did not experience any changes in working time regulations while in our panel, and thus cannot contribute to the identification of the effect of these changes on spousal labour supply. Our panel estimates thus focus on the 1998-2002 period.
} 


\section{Instrumental variable estimates of cross-hour effects}

There is a long standing tradition of labour supply models in which the labour supply decisions of married couples are treated as two-person games in which the labour supply of each spouse depends not only on own potential wage or unearned income, but also on the number of hours spent at work by the other spouse (see e.g. Elroy and Horney, 1981, Lundberg, 1988). These models are hard to estimate since they involve a system of two simultaneous equations in which wives' hours feature in the husbands' labour supply equation and vice versa, and good instruments for independent variation in the labour supply of one of the spouses are typically hard to find.

While the previous sections have highlighted the reduced-form effect of workweek regulations on spousal labour supply, in this section we use workweek regulations in an individual's firm as an instrument for her working hours in her spouse's labour supply equation. As well known, both reduced form parameters and IV estimates are of interest in their own right. The former is most policy relevant, as the Government can directly control the adoption of the shorter workweek, but of course cannot directly control spousal labour supply. Also, reduced form estimates would not require as an exclusion restriction that workweek regulations affect spousal labour supply only via their effect on the labour supply of directly treated employees. However, if one is willing to accept this (reasonable) exclusion restriction, IV estimates provide the appropriate structural parameter for measuring how labour supply responds to independent changes in labour supply of one’s spouse.

Below we estimate the impact of spousal hours on own hours, having instrumented spousal hours by AS-post variables. The regression results are reported in Table 11 for both husbands (Panel A) and wives (Panel B), using the same samples and specifications as in Tables 4, 6 and 7. Unsurprisingly, while we detect no significant cross-hour effect for wives on either the whole sample or any subsample, for husbands the cross-hour effect is always positive and significant. Among husbands the cross-hour effect in labour supply is about twice as large for managers and professionals than for other occupations, and in particular when their wives cut their labour supply by one hour, men in high occupations respond to by cutting their own labour supply by about 20 minutes. Also, cross hour effects are three times larger when there are young children in the household, relative to childless families. The quantitative response for fathers is about 35 minutes for each extra hour spent at home by their wives, thus suggesting that worktime policy evaluations restricted to direct labour supply effects may strongly underestimate its impact on the time spent by fathers with their young children. 
Overall, our estimated cross-hour effects lie between 0.2 and 0.6 for husbands and are negligible for wives. These results translate into social multipliers in households' labour supply lying between $1+0.2 / 2=1.1$ and $1+0.6 / 2=1.3$, which means that the equilibrium labour supply response to exogenous shocks affecting both spouses is up to 1.1 or 1.3 time the initial response. To the best of our knowledge, our paper provides one of the very first microeconomic evaluation of multiplier in labour supply at the household level.

\section{Conclusions}

This paper has investigated cross-hour effects on the labour supply of husbands and wives using independent variation in spousal hours generated by the introduction of the shorter workweek in France in the late 1990s. Our identification strategy exploits observed variation in working hours between treated and non-treated spouses, as well as staggered treatment dates among the treated.

We found that female and male employees treated by the shorter legal workweek reduced their weekly labour supply by about 2 hours, and did not experience any reduction in their monthly earnings. While wives of treated men did not seem to adjust their working time at either the intensive or extensive margins, husbands of treated wives responded by cutting their workweek by about half an hour to one hour, according to specifications and samples. In particular, this effect is stronger among managers and professionals, and fathers of young children. Most importantly, we find that husbands labour supply response is not associate to an earnings' loss, and reflect cuts in unpaid work. This result suggests significant spousal complementarities in leisure time for husbands, and namely when a wife's workweek is reduced, the increase in her leisure time raises the value of leisure for her husband and reduces his labour supply. Other mechanisms, working for example through changes in home production and its outsourcing to the market, do not seem consistent with the observed labour supply response of husbands at constant earnings.

Finally, by focusing on the direct effect on targeted population, most existing evaluations of workweek reduction policies are likely to underestimate the effect of these reforms on labour supply in general, and in particular on the time spent by parents with their young children. A simple back-of-envelope calculation suggests any policy that would neglect spousal labour supply spillover would likely underestimate the overall impact on male labour supply by about $13 \%$. 


\section{References}

Ahmed, Meherun, 2009, “The Added Worker Effect Revisited: the Aubry's Law in France as a Natural Experiment”, Unpublished Manuscript.

Alesina, Alberto, Edward L. Glaeser, and Bruce Sacerdote, 2005, "Work and Leisure in the U.S. and Europe: Why So Different?”, NBER Working Papers n 11278.

Askenazy, Philippe, 2008, “A Primer on the 35-hour Reduction in France: 1997-2007”, IZA $D P n^{\circ} 3402$.

Bloch-London,Catherine, Pham Trong-hiem, and Serge Zilberman, 2003, "La Mise en Oeuvre des 35 heures”, Données Sociales 2002-2003, INSEE, pp. 309-317 .

Chemin, Matthieu, and Etienne Wasmer, 2009, "The employment effects of 35-hour workweek regulation in France: using Alsace-Moselle local laws to build a diff-in-diff”, Journal of Labor Economics, 27(4): pp. 487-524.

Crépon, Bruno, and Francis Kramarz, 2002, "Employed 40 Hours or Not employed 39: Lessons from the 1981 Mandatory Reduction of the weekly Working Hours”, Journal of Political Economy.

Crépon, Bruno, Marie Leclair, and Sébastien Roux, 2004, "RTT, productivité et emploi : nouvelles estimations sur données d'entreprises”, Economie et statistique, $\mathrm{n}^{\circ}$ 376-377, pp. 55-89.

Cullen, Julie, and Jonathan Gruber, 2000, “Does Unemployment Insurance Crowd Out Spousal Labor Supply?”, Journal of Labor Economics, 18(3), pp. 546-572.

Elroy, Marjorie, and Marie Jean Horney, 1981, "Nash Bargained Household Decisions”, International Economic Review, Vol:2, pp. 333-349.

Entorf, Horst, Michel Gollac, and Francis Kramarz, 1999, “Technologies, wages, and worker selection”, Journal of Labor Economics, 17(3), pp. 464-491.

Estevao, Marcello, and Filipa Sa, 2008, "Are the French Happy with the 35-Hour Workweek?”, Economic Policy, 23 (55), 417-46”.

Fiole, Murielle, and Muriel Roger (2002) "Les effets sur l'emploi de la loi du 11 juin 1996 sur la réduction du temps de travail”, Economie et Statistique, n 357-358.

Gelber, Alexander M., 2010,“Taxation and the earnings of husbands and wives”, Unpublished Manuscript.

Glaeser, Edward L., Bruce I. Sacerdote and Jose A. Scheinkman, 2003, "The Social Multiplier”, Journal of the European Economic Association, vol. 1 (2-3), pages 345-353.

Goux, Dominique, and Eric Maurin, 1999, “The Persistence of Inter-industry Wage Differentials: a Reexamination on Matched Worker-firm Panel Data”, Journal of Labor Economics, 1999, vol. 17, no 3, p. 492-533. 
Gustman, Alan, and Thomas Steinmeier, 2000, "Retirement in Dual-Career Families: A Structural Model”, Journal of Labor Economics, 18(3), pp. 503-545.

Hunt, Jennifer, 1998, "Hours reduction as work sharing”, Brookings papers on economic activity, vol n 1, pp. 339-381.

Hurd, Michael D., 1988,’The Joint Retirement Decision of Husbands and Wives”, NBER Working Papers 2803.

International Labour Organisation, 2002, Key Indicators of the Labour Market: 2001-2002, Geneva.

Lundberg, Shelly, 1985, “The Added Worker Effect”, Journal of Labor Economics, January, pp. 11-37.

Lundberg, Shelly, 1988, "Labor Supply of Husbands and Wives: a Simultaneous Equation Model”, The Review of Economics and Statistics, pp. 224-34. 
Table 1

Descriptive Statistics

\begin{tabular}{|c|c|c|c|c|}
\hline \multirow[t]{3}{*}{ Panel A } & \multicolumn{4}{|c|}{ Males } \\
\hline & \multicolumn{2}{|c|}{ Full sample } & \multicolumn{2}{|c|}{ Employed only } \\
\hline & Wife not treated & Wife treated & Wife not treated & Wife treated \\
\hline Years of education & 12.7 & 12.4 & 12.9 & 12.5 \\
\hline Age & 42.6 & 41.9 & 41.7 & 41.0 \\
\hline High-skill occupation & 17.7 & 14.2 & 19.4 & 15.4 \\
\hline Private sector & 57.1 & 66.2 & 64.9 & 74.6 \\
\hline Spouse's year of educ. & 13.1 & 12.7 & 13.2 & 12.8 \\
\hline Spouse's age & 40.5 & 39.7 & 39.7 & 39.0 \\
\hline Spouse in high-skill occ. & 11.1 & 8.1 & 11.3 & 8.3 \\
\hline Spouse in private sector & 54.3 & 90.2 & 54.4 & 90.4 \\
\hline No. observations & 130,468 & 59,426 & 114,705 & 52,755 \\
\hline \multirow[t]{3}{*}{ Panel B } & \multicolumn{4}{|c|}{ Females } \\
\hline & \multicolumn{2}{|c|}{ Full sample } & \multicolumn{2}{|c|}{ Employed only } \\
\hline & $\begin{array}{l}\text { Husband not } \\
\text { treated }\end{array}$ & Husband treated & $\begin{array}{l}\text { Husband not } \\
\text { treated }\end{array}$ & Husband treated \\
\hline Years of Education & 12.6 & 12.4 & 13.0 & 12.8 \\
\hline Age & 39.4 & 39.5 & 39.5 & 39.5 \\
\hline High-skill occupation (\%) & 7.4 & 5.7 & 10.4 & 7.8 \\
\hline Private sector (\%) & 42.7 & 47.5 & 63.0 & 69.9 \\
\hline Spouse's year of educ. & 12.5 & 12.2 & 12.7 & 12.4 \\
\hline Spouse's age & 41.5 & 41.6 & 41.4 & 41.5 \\
\hline Spouse in high-skill occ. (\%) & 18.7 & 16.7 & 19.3 & 16.6 \\
\hline Spouse in private sector (\%) & 72.4 & 93.6 & 70.1 & 92.9 \\
\hline No. observations & 150,371 & 86,431 & 101,923 & 58,766 \\
\hline
\end{tabular}

Notes: interpretation of figures for main respondent and their spouses is as follows: The average number of years of education for men whose wife is not treated is 12.7. The average number of years of education for their wives is 13.1 . Source: Labour force surveys, 1994-2009, Insee. 
Table 2

Distribution of Own Firm Status, by Firm Status of the Spouse.

Panel A
Sample : Employed men

Wife treated

Wife not treated

54.2

45.8

22.8

23.0

100

71.0

29.0

29.0
- same year as wife's firm

Total
Sample : Employed women

Husband treated Husband not treated

Own firm never adopted shorter workweek

58.1

73.2

Own firm adopted shorter workweek

41.9

26.8

- not same year as wife's firm

21.3

26.8

- same year as wife's firm

20.6

Total

100

100

Panel A: Sample of married (or cohabiting) male employees, whose spouse is an employee.

Panel B: Sample of married (or cohabiting) female employees, whose spouse is an employee.

Reading: Among male employees whose spouse works in a treated firm, $45.8 \%$ are working in a treated firm. 
Table 3

Direct Effects of Workweek Reduction Agreements on Hours Worked and Earnings.

Panel A Wives

Hours Worked

(1)

$\begin{array}{lcc}\text { AS } & 1.36 & 1.01 \\ & (0.10) & (0.10) \\ \text { AS-post } & -1.81 & -1.91 \\ & (0.13) & (0.13) \\ \text { Additional controls } & \text { no } & \text { yes }\end{array}$

Earnings

(3)

(4)

\begin{tabular}{lllll} 
No. Observations & 189,894 & 189,894 & 160,046 & 160,046 \\
\hline
\end{tabular}

Panel B

Husbands

Hours Worked

Earnings

(1)

(2)

(3)

(4)

\begin{tabular}{lcccc} 
AS & -0.28 & -0.34 & 0.042 & 0.013 \\
& $(0.08)$ & $(0.08)$ & $(0.003)$ & $(0.003)$ \\
AS-post & -1.95 & -1.92 & 0.017 & 0.007 \\
\multirow{2}{*}{ Additional controls } & $(0.11)$ & $(0.11)$ & $(0.004)$ & $(0.004)$ \\
\multirow{2}{*}{ No. Observations } & no & yes & no & yes \\
\hline \hline
\end{tabular}

Notes: The main samples (columns 1 and 2) include married (or cohabiting) individuals, whose spouse is an employee. Columns 3 and 4 refer to the subsample on which earnings are collected (from 2003 onward, information is collected on one third of the LFS sample only). The table shows the results of regressing spouse's hours (YS) and earnings (WS) on the status of spouse's firm (AS) and on whether an agreement is on in spouse's firm (AS-post). Baseline control variables are 15 year dummies and a dummy indicating whether spouse works in public sector. Additional controls are spouse's years of education, age, age square and 16 industry dummies. Source: Labour force surveys, 1994-2009. 
Table 4

Cross Effects of the Shorter Workweek on Employment and Hours Worked.

\begin{tabular}{|c|c|c|c|c|c|}
\hline \multirow[t]{3}{*}{ Panel A } & \multicolumn{5}{|c|}{ Husbands } \\
\hline & \multicolumn{2}{|c|}{ Employment } & \multicolumn{3}{|c|}{$\begin{array}{c}\text { Hours Worked } \\
\text { (conditional on emplovment) }\end{array}$} \\
\hline & (1) & (2) & (3) & (4) & (5) \\
\hline \multirow[t]{2}{*}{$A S$} & 0.0062 & 0.0021 & -0.11 & -0.11 & -0.16 \\
\hline & $(0.0022)$ & $(0.0020)$ & $(0.10)$ & $(0.10)$ & $(0.11)$ \\
\hline \multirow[t]{2}{*}{ AS-post } & -0.0037 & -0.0028 & -0.44 & -0.45 & -0.50 \\
\hline & $(0.0031)$ & $(0.0027)$ & $(0.14)$ & $(0.14)$ & $(0.15)$ \\
\hline \multirow[t]{2}{*}{$A$} & - & - & -0.05 & -0.09 & -0.17 \\
\hline & & & $(0.11)$ & $(0.11)$ & $(0.12)$ \\
\hline \multirow[t]{2}{*}{ A-post } & - & - & -1.96 & -1.96 & -2.02 \\
\hline & & & $(0.14)$ & $(0.14)$ & $(0.16)$ \\
\hline Add. Controls & no & yes & no & yes & yes \\
\hline No. Observations & 189,894 & 189,894 & 167,460 & 167,460 & 156,392 \\
\hline
\end{tabular}

Panel B

Employment

(1)

(2)

$\begin{array}{cc}0.0164 & 0.0146 \\ (0.0027) & (0.0026) \\ -0.0032 & -0.0041 \\ (0.0038) & (0.0037)\end{array}$

A

AS

AS-post

(0.0038)

(0.0037)

A-post

Add. Controls

no

yes

$\begin{array}{lllll}\text { No. Observations } \quad 236,802 & 236,802 & 160,689 & 160,689 & 150,371\end{array}$

Wives

Hours Worked

(conditional on employment)

(3)

(4)

$-0.27$

(0.11)

(0.10) (0.10)

$0.12 \quad 0.05$

0.06

(0.14)

(0.14)

(0.15)

1.76

1.22

1.22

(0.12)

(0.12)

(0.13)

$-1.86$

$-1.88$

$-1.86$

(0.16)

(0.16)

no

yes

(0.18)

yes

Notes: The main samples (columns 1 and 2) are the same as in Table 2. Columns 3 and 4 refer to the employed subsamples, and column 5 further excludes respondents who were treated at the same time of their spouse. The table shows the results of regressing individuals' employment $(E)$ and hours worked $(H)$ on the status of spouse's firm (AS), on the status of own firm (A), on whether an agreement is on in spouse's firm (AS-post) and on whether an agreement is on in own firm (A-post). In columns 1 and 2, baseline control variables are 15 year dummies and a dummy indicating whether spouse works in the public sector. Additional controls in column 2 are spouse's years of education, age and age square, and respondent years of education, age and age square. For columns 3 to 5, baseline controls are 15 year dummies, a public sector dummy, a wage-earner dummy and a dummy indicating whether spouse works in the public sector. Additional controls in columns 4 and 5 include spouse's years of education, age, age square and 16 industry dummies, and respondent years of education, age, age square and 16 industry dummies. Source: Labour force surveys, 1994-2009. 
Table 5

Cross Effects of the Shorter Workweek on Husbands' Earnings and Types of Hours

Worked.

\begin{tabular}{|c|c|c|c|c|c|c|}
\hline & \multicolumn{2}{|c|}{ Earnings } & \multicolumn{4}{|c|}{ Hours concept } \\
\hline & & & $\begin{array}{l}\text { Usual } \\
\text { hours } \\
\left(H_{u}\right)\end{array}$ & $\begin{array}{c}\text { Actual-Usual } \\
\text { hours } \\
\left(H-H_{u}\right)\end{array}$ & $\begin{array}{l}\text { Overtime } \\
\text { hours } \\
\left(H-H_{u}\right)^{+}\end{array}$ & $\begin{array}{c}\text { Unworked } \\
\text { hours } \\
\left(H-H_{u}\right)^{-}\end{array}$ \\
\hline$A S$ & $\begin{array}{c}-0.018 \\
(0.003)\end{array}$ & $\begin{array}{c}-0.016 \\
(0.003)\end{array}$ & $\begin{array}{l}-0.14 \\
(0.06)\end{array}$ & $\begin{array}{c}0.04 \\
(0.10)\end{array}$ & $\begin{array}{c}0.00 \\
(0.03)\end{array}$ & $\begin{array}{c}0.04 \\
(0.10)\end{array}$ \\
\hline AS-post & $\begin{array}{c}0.008 \\
(0.005)\end{array}$ & $\begin{array}{c}0.003 \\
(0.005)\end{array}$ & $\begin{array}{l}-0.01 \\
(0.09)\end{array}$ & $\begin{array}{l}-0.59 \\
(0.17)\end{array}$ & $\begin{array}{l}-0.06 \\
(0.05)\end{array}$ & $\begin{array}{l}-0.53 \\
(0.16)\end{array}$ \\
\hline$A$ & $\begin{array}{c}0.008 \\
(0.003)\end{array}$ & $\begin{array}{c}0.008 \\
(0.003)\end{array}$ & $\begin{array}{c}0.02 \\
(0.06)\end{array}$ & $\begin{array}{l}-0.14 \\
(0.10)\end{array}$ & $\begin{array}{l}-0.01 \\
(0.03)\end{array}$ & $\begin{array}{l}-0.13 \\
(0.10)\end{array}$ \\
\hline A-post & $\begin{array}{c}0.005 \\
(0.005)\end{array}$ & $\begin{array}{c}0.007 \\
(0.005)\end{array}$ & $\begin{array}{l}-1.98 \\
(0.09)\end{array}$ & $\begin{array}{l}-0.33 \\
(0.16)\end{array}$ & $\begin{array}{c}0.09 \\
(0.04)\end{array}$ & $\begin{array}{l}-0.43 \\
(0.15)\end{array}$ \\
\hline No Obs. & 124417 & 101138 & 101138 & 101138 & 101138 & 101138 \\
\hline
\end{tabular}

Samples: Column 1: married (or cohabiting) male employees whose spouse is an employee; Columns 2-6: 19942002 sub-sample with usual weekly hours. Regressions include same set of control variables as model (4) in Table 4. Source: Labour force surveys, 1994 to 2009 (column 1) and 1994 to 2002 (columns 2 to 6). 
Table 6

Direct and Cross Effects of the Shorter Workweek in Wives' Firms, by Husband's Occupation.

\begin{tabular}{lccc}
\hline \multirow{2}{*}{ Panel A } & \multicolumn{3}{c}{ Sample: Employed Men, high-skill occupations } \\
& Wife's hours & Husband's hours & Husband's hours $\geq 45$ \\
& $(1)$ & $(2)$ & $(3)$ \\
\cline { 2 - 4 } AS & 1.26 & 0.30 & 0.006 \\
AS-post & $(0.28)$ & $(0.31)$ & $(0.009)$ \\
& -2.32 & -0.81 & -0.003 \\
No. Observations & $(0.36)$ & $(0.40)$ & $(0.012)$ \\
\hline \multirow{2}{*}{ Panel B } & 30,432 & 30,432 & 30,432 \\
& \multicolumn{2}{c}{ Sample: Employed Men, other occupations } \\
& Wife's hours & Husband's hours & Husband's hours $\geq 45$ \\
AS & $(1)$ & $(2)$ & $(3)$ \\
AS-post & 0.94 & -0.10 & -0.003 \\
& $(0.11)$ & $(0.11)$ & $(0.003)$ \\
& -1.72 & -0.32 & -0.006 \\
No. Observations & $(0.15)$ & $(0.15)$ & $(0.004)$ \\
\hline \hline
\end{tabular}

Notes: high-skill occupations include managers, professionals, engineers and associate occupations. In column 1, control variables are as in column 4 of Table 3 . In columns 2 and 3, control variables are as in column 4 of Table 4. 
Table 7

Direct and Cross Effects of the Shorter Workweek in Wives' Firms, by Family Types.

\begin{tabular}{|c|c|c|c|}
\hline \multirow[t]{2}{*}{ Panel A } & \multicolumn{3}{|c|}{ Sample: Employed Men, Households with at least one child aged 0-6 } \\
\hline & $\begin{array}{l}\text { Wife's hours } \\
\text { (1) }\end{array}$ & $\begin{array}{l}\text { Husband's hours } \\
\text { (2) }\end{array}$ & $\begin{array}{c}\text { Husband's hours } \geq 45 \\
\text { (3) }\end{array}$ \\
\hline AS & $\begin{array}{c}0.48 \\
(0.22)\end{array}$ & $\begin{array}{l}-0.01 \\
(0.21)\end{array}$ & $\begin{array}{c}0.002 \\
(0.006)\end{array}$ \\
\hline AS-post & $\begin{array}{l}-1.30 \\
(0.31)\end{array}$ & $\begin{array}{l}-0.81 \\
(0.29)\end{array}$ & $\begin{array}{l}-0.028 \\
(0.008)\end{array}$ \\
\hline No. Observations & 39,468 & 39,468 & 39,468 \\
\hline \multirow[t]{2}{*}{ Panel B } & \multicolumn{3}{|c|}{ Sample: Employed Men, Other households } \\
\hline & $\begin{array}{l}\text { Wife's hours } \\
\text { (1) }\end{array}$ & $\begin{array}{c}\text { Husband's hours } \\
\text { (2) }\end{array}$ & $\begin{array}{c}\text { Husband's hours } \geq 45 \\
\text { (3) }\end{array}$ \\
\hline AS & $\begin{array}{l}1.17 \\
(0.11)\end{array}$ & $\begin{array}{l}-0.14 \\
(0.12)\end{array}$ & $\begin{array}{l}-0.010 \\
(0.003)\end{array}$ \\
\hline AS-post & $\begin{array}{l}-2.08 \\
(0.16)\end{array}$ & $\begin{array}{l}-0.34 \\
(0.16)\end{array}$ & $\begin{array}{l}-0.003 \\
(0.005)\end{array}$ \\
\hline No. Observations & 127,992 & 127,992 & 127,992 \\
\hline
\end{tabular}

Notes: control variables are as in Table 6. 
Table 8

Direct and Cross Effects of the Shorter Workweek in Wives' firms: Alternative Specifications.

\begin{tabular}{lccc}
\hline \hline & \multicolumn{3}{c}{ Sample: Employed Men } \\
& Wife's hours & Wife's earnings & Husband's hours \\
& $(1)$ & $(2)$ & $(3)$ \\
AS* $(t>2002)$ & -1.87 & 0.009 & -0.47 \\
& $(0.20)$ & $(0.011)$ & $(0.20)$ \\
AS-post*( $t \leq 2002)$ & -1.85 & -0.005 & -0.40 \\
& $(0.20)$ & $(0.007)$ & $(0.20)$ \\
AS & 1.19 & 0.064 & 0.00 \\
& $(0.14)$ & $(0.005)$ & $(0.14)$ \\
AS* $(1998 \leq t \leq 2002)$ & -0.47 & -0.002 & -0.26 \\
& $(0.20)$ & $(0.007)$ & $(0.20)$ \\
$A-p o s t$ & - & -1.96 \\
No. Observations & 167,460 & 141,623 & $(0.14)$ \\
& & & -0.09 \\
\hline \hline
\end{tabular}

Notes: In columns 1 and 2, control variables are the same as in columns 2 and 4 of Table 3. In column 3 , control variables are the same as in column 4 of Table 4. 
Table 9

Number of Observations per Respondent and Proportion of Switchers

\begin{tabular}{cccc}
\hline \hline & \multicolumn{3}{c}{ Sample male respondents } \\
$\begin{array}{c}\text { Number of obs. } \\
\text { per respondent }\end{array}$ & $\begin{array}{c}\text { Total number } \\
\text { respondents }\end{array}$ & $\begin{array}{c}\text { Total number } \\
\text { observations }\end{array}$ & $\begin{array}{c}\text { Proportion of changes } \\
\text { in spouses' Firms }\end{array}$ \\
1 & 26231 & 26231 & - \\
2 & 13916 & 27832 & $11,9 \%$ \\
3 & 9073 & 27219 & $17,9 \%$ \\
All & 49220 & 81282 & $10,1 \%$ \\
Number of obs. & Total number & Total number & Proportion of changes \\
per respondent & respondents & observations & in spouses’ Firms \\
1 & 31110 & 31110 & - \\
2 & 17292 & 34584 & $14,1 \%$ \\
3 & 11901 & 35703 & $22,6 \%$ \\
All & 60303 & 101397 & $12,8 \%$ \\
\hline
\end{tabular}

Notes: the sample includes individuals living in couple and whose spouse is an employee. Source: Labour Force Surveys, 1998 to 2002, Insee.

Reading: 13916 male respondents are observed at two dates and 11.9\% have a spouse whose firm passed an agreement between these two dates. 
Table 10

Cross Effects of the Shorter Workweek on Employment and Hours: Panel Regressions

Cross effects on husbands

Type of hours

\begin{tabular}{|c|c|c|c|c|c|c|c|}
\hline & $\begin{array}{c}\text { Employment } \\
\text { (1) }\end{array}$ & $\begin{array}{c}\text { Hours } \\
\text { (2) }\end{array}$ & $\begin{array}{c}\text { Earnings } \\
\text { (3) }\end{array}$ & $\begin{array}{c}\text { Usual } \\
\text { hours } \\
(4)\end{array}$ & $\begin{array}{l}\text { Actual- } \\
\text { Usual } \\
\text { (5) }\end{array}$ & $\begin{array}{l}\text { Overtime } \\
\text { hours } \\
(6)\end{array}$ & $\begin{array}{l}\text { Unworked } \\
\text { hours } \\
\text { (7) }\end{array}$ \\
\hline AS & $\begin{array}{l}.005 \\
(.006)\end{array}$ & $\begin{array}{l}.45 \\
(.47)\end{array}$ & $\begin{array}{c}.005 \\
(.009)\end{array}$ & $\begin{array}{l}-.10 \\
(.15)\end{array}$ & $\begin{array}{l}.48 \\
(.47)\end{array}$ & $\begin{array}{l}.12 \\
(.12)\end{array}$ & $\begin{array}{c}.36 \\
(.44)\end{array}$ \\
\hline$A S^{*} p o s t$ & $\begin{array}{l}-.006 \\
(.004)\end{array}$ & $\begin{array}{l}-.40 \\
(.35)\end{array}$ & $\begin{array}{l}-.000 \\
(.006)\end{array}$ & $\begin{array}{c}.15 \\
(.11)\end{array}$ & $\begin{array}{l}-.76 \\
(.34)\end{array}$ & $\begin{array}{l}.04 \\
(.09)\end{array}$ & $\begin{array}{l}-.80 \\
(.32)\end{array}$ \\
\hline$A$ & - & $\begin{array}{l}.19 \\
(.42)\end{array}$ & $\begin{array}{l}-.005 \\
(.008)\end{array}$ & $\begin{array}{c}.61 \\
(.14)\end{array}$ & $\begin{array}{l}-.26 \\
(.42)\end{array}$ & $\begin{array}{l}-.17 \\
(.11)\end{array}$ & $\begin{array}{c}-.09 \\
(.39)\end{array}$ \\
\hline$A^{*}$ post & - & $\begin{array}{l}-1.22 \\
(.34)\end{array}$ & $\begin{array}{l}-.009 \\
(.006)\end{array}$ & $\begin{array}{l}-1.52 \\
(.11)\end{array}$ & $\begin{array}{c}.33 \\
(.34)\end{array}$ & $\begin{array}{l}.19 \\
(.09)\end{array}$ & $\begin{array}{l}.13 \\
(.31)\end{array}$ \\
\hline Obs. & 81,282 & 63,796 & 63,796 & 56,941 & 56,941 & 56,941 & 56,941 \\
\hline
\end{tabular}

Cross effect on wives

\begin{tabular}{|c|c|c|c|c|c|}
\hline \multirow[b]{2}{*}{ Employment } & \multirow[b]{2}{*}{ Hours } & \multirow[b]{2}{*}{ Earnings } & \multicolumn{3}{|c|}{ Type of hours } \\
\hline & & & $\begin{array}{lc}\text { Usual } & \text { Actual- } \\
\text { hours } & \text { Usual }\end{array}$ & $\begin{array}{l}\text { Overtime } \\
\text { hours }\end{array}$ & $\begin{array}{l}\text { Unworked } \\
\text { hours }\end{array}$ \\
\hline
\end{tabular}

(1) (2) (3)

(4) (5) (6) (7)

\begin{tabular}{|c|c|c|c|c|c|c|c|}
\hline$A S$ & $\begin{array}{c}-.001 \\
(0,006)\end{array}$ & $\begin{array}{l}-.24 \\
(.41)\end{array}$ & $\begin{array}{c}-.002 \\
(.009)\end{array}$ & $\begin{array}{l}.25 \\
(.16)\end{array}$ & $\begin{array}{c}.11 \\
(.40)\end{array}$ & $\begin{array}{l}-.01 \\
(.09)\end{array}$ & $\begin{array}{c}.12 \\
(.38)\end{array}$ \\
\hline$A S^{*} p o s t$ & $\begin{array}{l}-.003 \\
(.005)\end{array}$ & $\begin{array}{c}.33 \\
(.31)\end{array}$ & $\begin{array}{l}.006 \\
(.007)\end{array}$ & $\begin{array}{l}.15 \\
(.13)\end{array}$ & $\begin{array}{c}.04 \\
(.31)\end{array}$ & $\begin{array}{l}-.07 \\
(.07)\end{array}$ & $\begin{array}{l}.12 \\
(.29)\end{array}$ \\
\hline$A$ & - & $\begin{array}{l}.28 \\
(.45)\end{array}$ & $\begin{array}{c}.013 \\
(.010)\end{array}$ & $\begin{array}{l}0.89 \\
(.18)\end{array}$ & $\begin{array}{l}-.43 \\
(.44)\end{array}$ & $\begin{array}{c}-.11 \\
(.10)\end{array}$ & $\begin{array}{l}-.33 \\
(.42)\end{array}$ \\
\hline A*post & - & $\begin{array}{l}-1.21 \\
(.35)\end{array}$ & $\begin{array}{c}-.010 \\
(.008)\end{array}$ & $\begin{array}{l}-1.50 \\
(.14)\end{array}$ & $\begin{array}{c}.31 \\
(.34)\end{array}$ & $\begin{array}{c}.04 \\
(.08)\end{array}$ & $\begin{array}{l}.27 \\
(.32)\end{array}$ \\
\hline Obs. & 101,397 & 67,133 & 67,133 & 63,236 & 63,236 & 63,236 & 63,236 \\
\hline
\end{tabular}

Notes: the main sample (column 1) is the same as in Table 3. Columns 2 and 3 refer to the employed subsample whereas columns 4 to 7 further exclude workers without usual weekly hours. Controls include individuals fixed effects as well as the same baseline and additional control variables as in Table 4 Source: Labour Force surveys, 1998 to 2002, Insee. 
Table 11

Cross-hour Effects, IV Estimates.

\begin{tabular}{lccccc}
\hline \hline Panel A & \multicolumn{5}{c}{ Sample: Employed men } \\
& All & Highly & Other & 1 or more & Other \\
& & skilled & Occup. & child 0-6 & households \\
& $(1)$ & $(2)$ & $(3)$ & $(4)$ & $(5)$ \\
Wives' hours & 0.23 & 0.34 & 0.18 & 0.59 & 0.16 \\
& $(0.07)$ & $(0.16)$ & $(0.08)$ & $(0.23)$ & $(0.07)$ \\
No. Observations & 167,460 & 30,432 & 137,028 & 39,468 & 127,992 \\
\hline Panel B & & & Sample: Employed women & \\
& & Dependent variable: Weekly hours worked & \\
& All & Highly & Other & 1 or more & Other \\
& & skilled & Occup. & child 0-6 & households \\
& $(1)$ & $(2)$ & $(3)$ & $(4)$ & $(5)$ \\
Husbands' hours & -0.02 & 0.08 & -0.07 & -0.23 & 0.04 \\
& $(0.07)$ & $(0.23)$ & $(0.07)$ & $(0.15)$ & $(0.08)$ \\
No. Observations & 160,689 & 15,217 & 145,472 & 36,959 & 123,730 \\
\hline
\end{tabular}

Panel A: Estimates reported show the effect of spousal labour supply on the main respondent's labour supply, using treatment of spousal firm (AS-post) as an instrument. The corresponding reduced-form results are reported in Tables 4, 6 and 7. Controls included are a dummy variable for type of spouse firm (AS), 15 year dummies, a wage-earner dummy, a public sector dummy, spouse's years of education, age, age square, 16 spouse's industry dummies and a dummy indicating whether spouse works in public sector. 


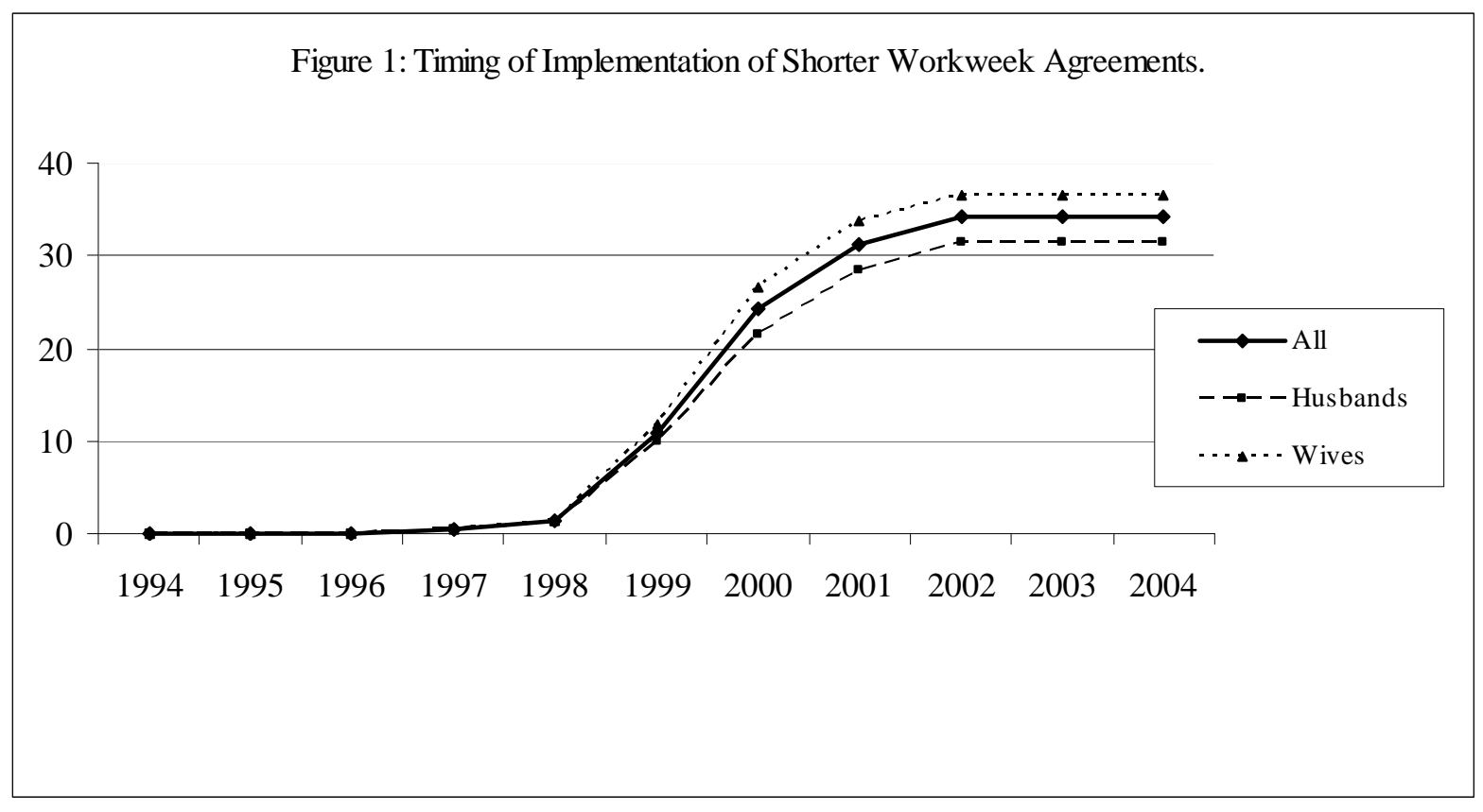



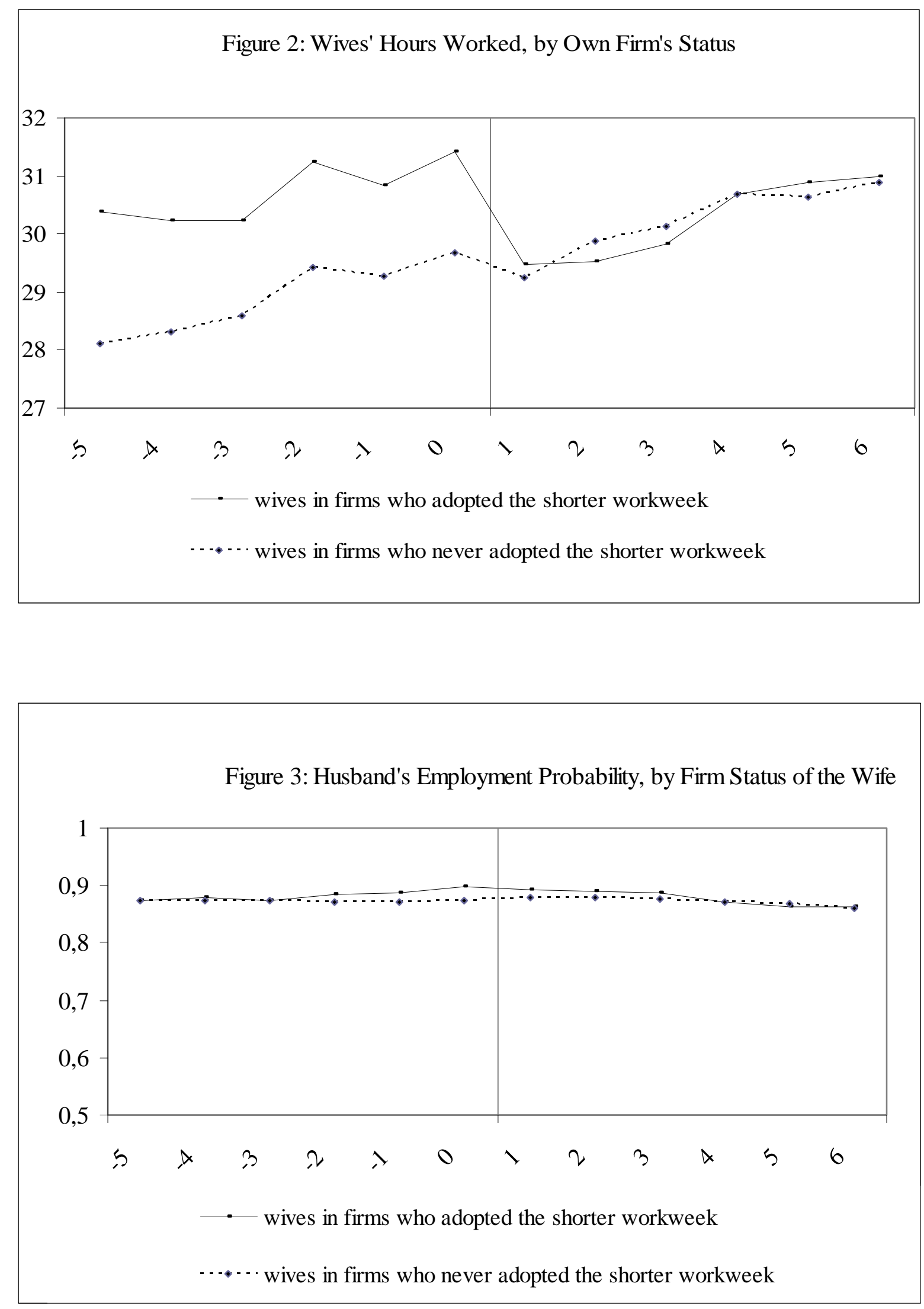

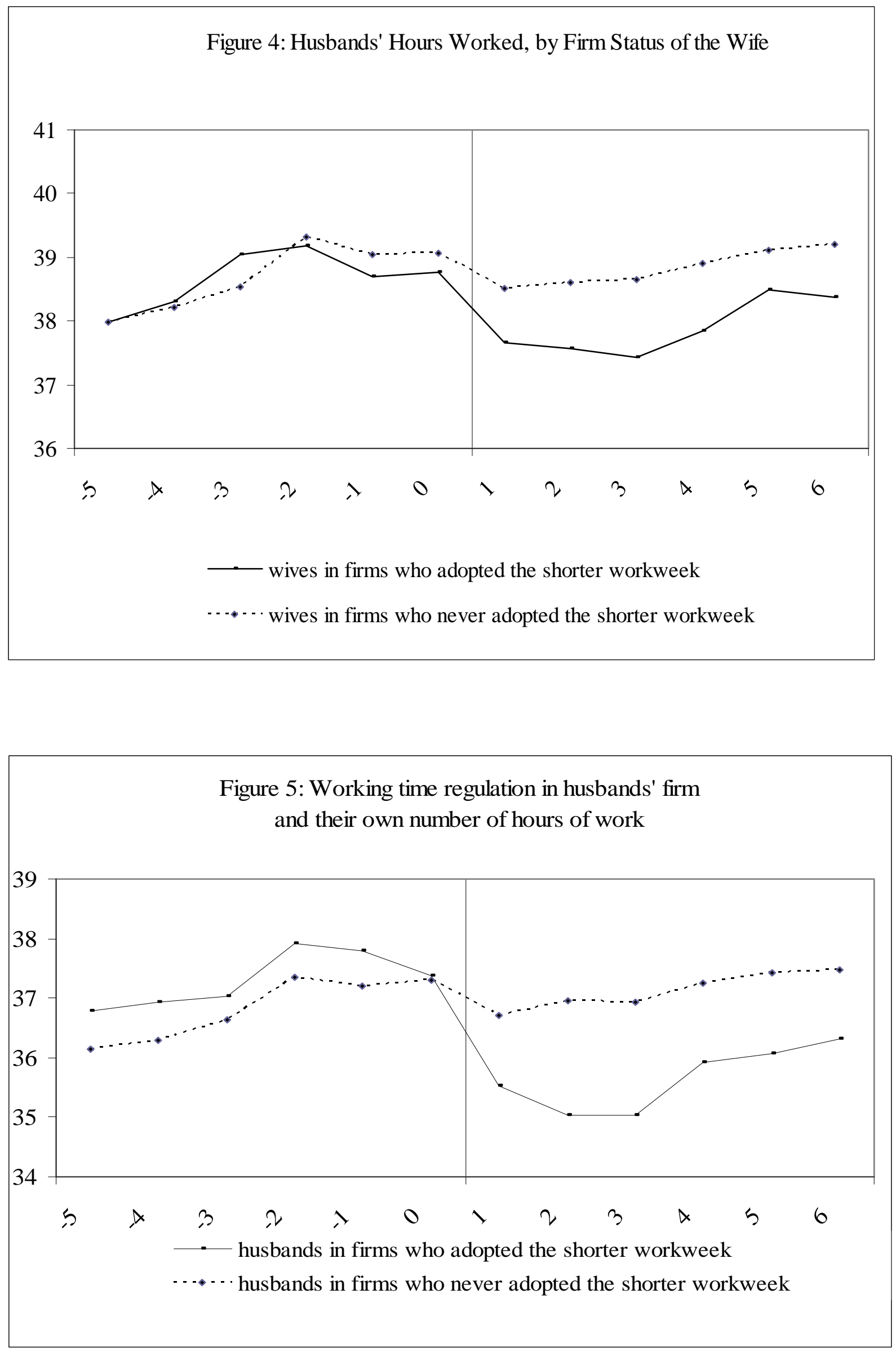


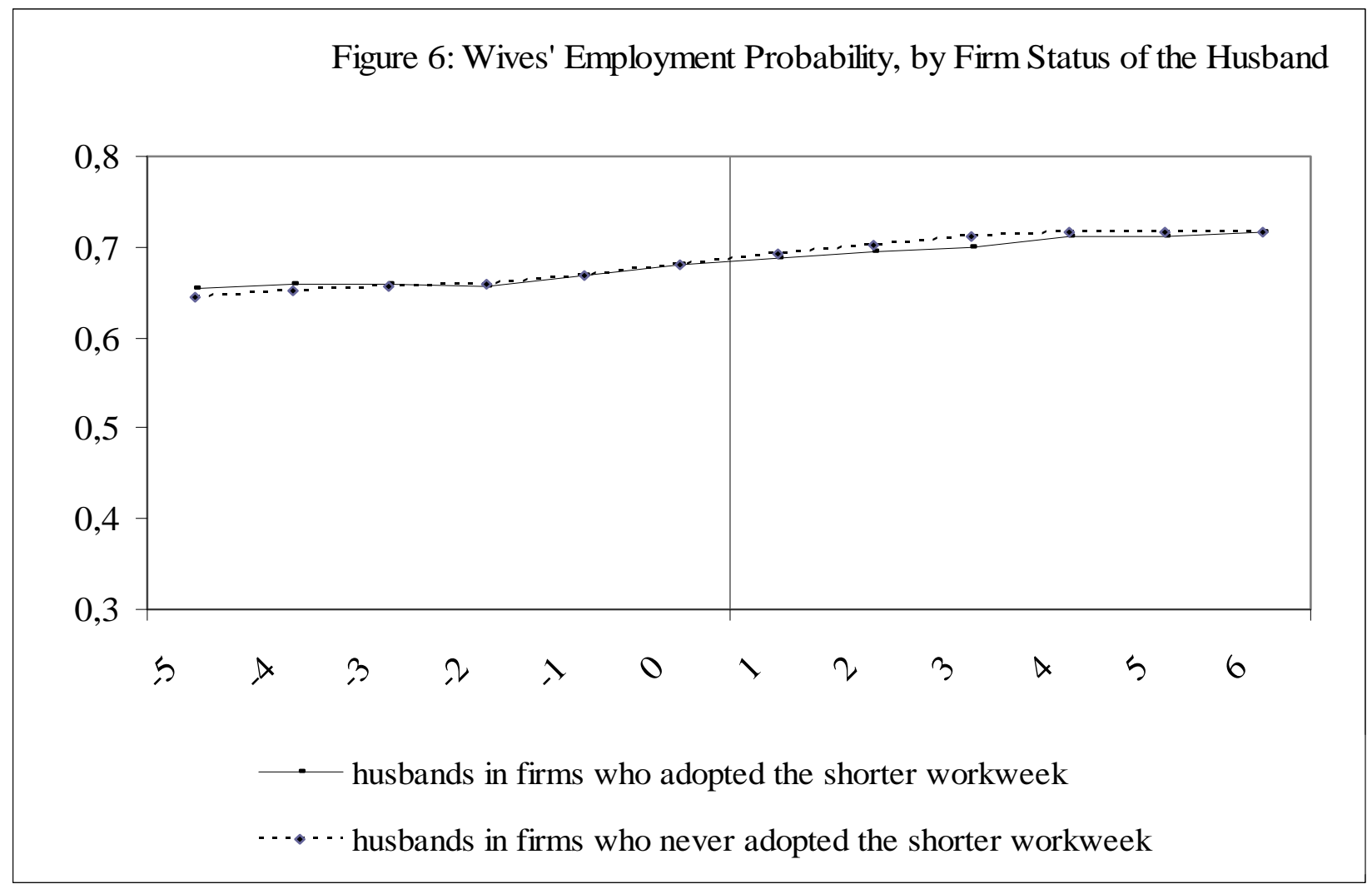

Figure 7: Wives' Hours Worked, By Firm Status of the Husband

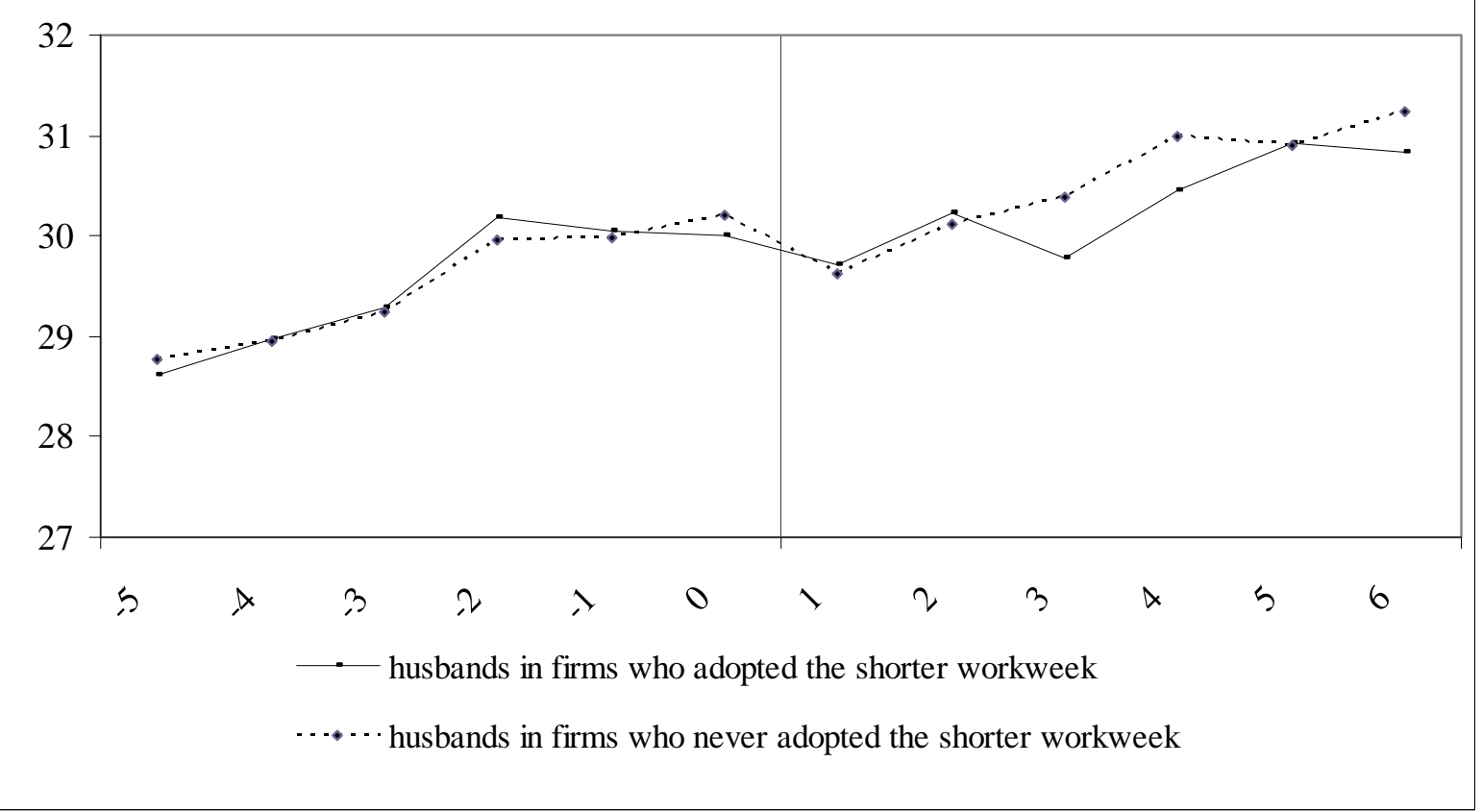


Table A1

Direct Effects of the Shorter Workweek on Hours Worked and Earnings. Subsample of employed individuals.

Panel A

Hours Worked

(1)

(2)

Earnings

Wives

$1.34 \quad 0.99$

(0.10)

(0.10)

$-1.89$

(0.14)

(0.14)

yes

167460

Husbands

Panel B

167460

(1)

(3)

(4)

$\begin{array}{cc}0.086 & 0.064 \\ (0.004) & (0.004) \\ 0.002 & -0.002 \\ (0.006) & (0.006) \\ \text { No } & \text { yes }\end{array}$

141623

141623

Hours Worked

Earnings

(1) (2) - (3)

(4)

$\begin{array}{lcccc}\text { AS } & -0.28 & -0.32 & 0.035 & 0.009 \\ & (0.09) & (0.09) & (0.003) & (0.003) \\ \text { AS-post } & -2.12 & -2.08 & 0.013 & 0.004 \\ \text { Add. Controls } & (0.13) & (0.13) & (0.005) & (0.005) \\ & \text { no } & \text { yes } & \text { no } & \text { yes } \\ \text { No. Observations } & 160689 & 160689 & 135729 & 135729\end{array}$

Notes: The main samples include married (or cohabiting) employees, whose spouse is an employee. Columns 3 and 4 refer to the sub-samples for which spouses' earnings are observed. The table shows the results of regressing spouse's hours (YS) and earnings (WS) on the status of spouse's firm (AS) and on whether an agreement is on in spouse' firm (AS-post). Same controls as in Table 3. Source: LFS, 1994-2009. 
Table A2

Usual Hours, Actual Hours and Husbands' Monthly Earnings.

Dep. Variable: monthly earnings

\begin{tabular}{|c|c|c|c|c|c|c|}
\hline & \multicolumn{2}{|c|}{ All } & \multicolumn{2}{|c|}{ Pre-Reform } & \multicolumn{2}{|c|}{ Post-reform } \\
\hline & (1) & (2) & (3) & (4) & (5) & (6) \\
\hline $\begin{array}{l}\text { Usual weekly hours } \\
\left(H_{u}\right)\end{array}$ & $\begin{array}{c}6.48 \\
(0.28)\end{array}$ & $\begin{array}{c}6.50 \\
(0.28)\end{array}$ & $\begin{array}{c}6.29 \\
(0.31)\end{array}$ & $\begin{array}{c}6.31 \\
(0.31)\end{array}$ & $\begin{array}{c}9.16 \\
(0.32)\end{array}$ & $\begin{array}{c}9.25 \\
(0.32)\end{array}$ \\
\hline $\begin{array}{l}\text { Actual- Usual weekly } \\
\text { hours }\left(H-H_{u}\right)\end{array}$ & $\begin{array}{c}0.30 \\
(0.16)\end{array}$ & & $\begin{array}{c}0.29 \\
(0.18)\end{array}$ & & $\begin{array}{c}0.43 \\
(0.15)\end{array}$ & \\
\hline $\begin{array}{l}\text { Overtime hours } \\
\left(H-H_{u}\right)^{+}\end{array}$ & & $\begin{array}{c}2.52 \\
(0.59)\end{array}$ & & $\begin{array}{c}2.36 \\
(0.65)\end{array}$ & & $\begin{array}{c}4.25 \\
(0.55)\end{array}$ \\
\hline $\begin{array}{l}\text { Unworked hours } \\
\left(H-H_{u}\right)^{-}\end{array}$ & & $\begin{array}{c}0.05 \\
(0.17)\end{array}$ & & $\begin{array}{c}0.06 \\
(0.19)\end{array}$ & & $\begin{array}{l}-0.03 \\
(0.17)\end{array}$ \\
\hline Observations & 101138 & 101138 & 89822 & 89822 & 11316 & 11316 \\
\hline
\end{tabular}


Table A3

Overtime hours and paid holidays.

$\begin{array}{cc}\text { One or more week } & \text { Positive overtime } \\ \text { of paid holidays } & \text { hours } \\ \text { not taken } & (\%)\end{array}$

(\%)

Number of
overtime hours
(conditional on
overtime)

Fraction of overtime hours that are paid

(\%)

\section{Men}

\section{All men}

12.4

23.0

7h06m

39.0

High-skill occupations

14.0

36.6

$8 \mathrm{~h} 47 \mathrm{~m}$

16.4

Other occupations

11.9

20.4

$6 \mathrm{~h} 31 \mathrm{~m}$

46.7

Women

$\begin{array}{lllll}\text { All women } & 15.3 & 16.5 & 5 \mathrm{~h} 16 \mathrm{~m} & 26,5 \\ \text { High-skill occupations } & 13.4 & 31.9 & 6 \mathrm{~h} 53 \mathrm{~m} & 13.0 \\ \text { Other occupations } & 15.6 & 14.8 & 4 \mathrm{~h} 53 \mathrm{~m} & 29.7\end{array}$

Notes: high-skill occupations include managers, professionals, engineers and associate occupations. Sample: married or cohabitating individuals, whose spouse in an employee (column 1). Columns 2, 3 and 4 exclude employees with no usual hours. Source: Labour force surveys, 2003-2009. 

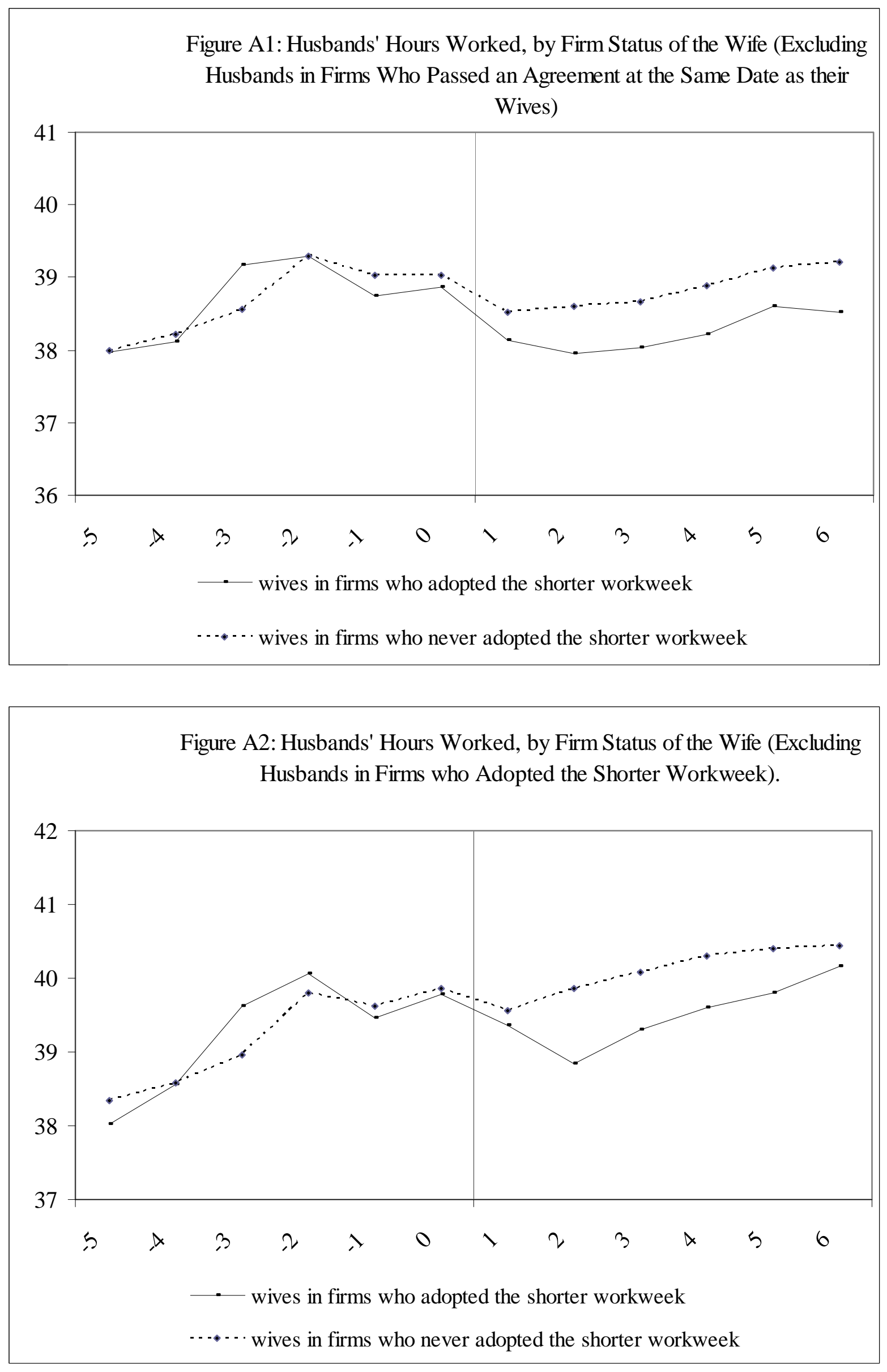